\title{
Endophytes isolated from passion fruit plants: molecular identification, chemical characterization and antibacterial activity of secondary metabolites
}

\author{
Mariana Sanches Santos ${ }^{1}$, Ravely Casarotti Orlandelli ${ }^{1}$, Julio Cesar Polonio ${ }^{1}$, Marcos Alessandro dos Santos Ribeiro ${ }^{2}$, \\ Maria Helena Sarragiotto ${ }^{2}$, João Lúcio Azevedo ${ }^{3}$, João Alencar Pamphile ${ }^{1^{*}}$ \\ ${ }^{1}$ Departamento de Biotecnologia, Genética e Biologia Celular, Universidade Estadual de Maringá, Maringá, Paraná, Brazil. \\ ${ }^{2}$ Departamento de Química, Universidade Estadual de Maringá, Maringá, Paraná, Brazil. \\ ${ }^{3}$ Escola Superior de Agricultura "Luiz de Queiroz", Universidade de São Paulo, Piracicaba, São Paulo, Brazil.
}

\section{ARTICLE INFO \\ Article history: \\ Received on: 14/07/2016 \\ Accepted on: 24/11/2016 \\ Available online: 30/04/2017}

\section{Key words:}

Endophytic fungi, antimicrobial action,

Passiflora genus, rDNA

sequencing, thin layer

chromatography.

\begin{abstract}
Endophytic fungi inhabit the interior of healthy plants without any apparent harm and may synthesize bioactive compounds, which constitute an alternative for the control of human pathogens. Current study reports the molecular identification of two endophytes from passion fruit plants: isolate PE1-13 (from Passiflora edulis $\mathrm{f}$. flavicarpa) has been identified as Phyllosticta sp. and isolate PA8-2 (from Passiflora alata) is a Cercospora beticola strain. Thin layer chromatography showed that steroids and triterpenoids were present in the secondary metabolites produced by the two endophytes. The antibacterial assay against Enterococcus faecalis, Salmonella typhi and Streptococcus pyogenes indicated that the fungal metabolites reduced up to $98.1 \pm 0.5 \%$ of bacterial growth. Results suggest that these endophytes are capable of producing antibacterial compounds.
\end{abstract}

\section{INTRODUCTION}

Although enterococci are natural colonizers of the gastrointestinal tract in most humans and animals, the bacterial group may cause nosocomial infections (Arias and Murray, 2012) since Enterococcus faecalisis a highly relevant pathogenic species (Gregersen et al., 2010). Glycopeptide antibiotics, including vancomycin and teicoplanin, are often used against Enterococcus infections because the bacterial group is multiresistant to several antibiotic classes (Arias and Murray, 2008).

\footnotetext{
* Corresponding Author

João Alencar Pamphile, Departamento de Biotecnologia, Genética e Biologia Celular, Universidade Estadual de Maringá, Maringá, Paraná, Brazil. Email: prof.pamphile @ gmail.com
}

However, glycopeptide resistance in enterococci has been reported (Breidenstein et al., 2015). Approximately 200,000 people die annually worldwide as a result of typhoid fever, a systemic disease caused by Salmonella typhi (Crump and Mintz, 2010; Butler, 2011). Typhus is an important public health problem and there is an increasing need for antimicrobial treatment since its resistance to ciprofloxacin, ceftriaxone and azithromycin has been proved (Wong et al., 2014). Streptococcus pyogenesis transmitted primarily through direct contact with skin lesions or throat secretions of infected patients and colonizes the human skin and throat by causing pharyngitis, impetigo, necrotizing fasciitis and streptococcal toxic-shock syndrome (Wasserzug et al., 2009; Siljander et al., 2010). Some S. pyogenes isolates have been reported to be resistant to erythromycin and tetracycline (RubioLópez et al., 2012; Silva-Costa et al., 2012). 
Considering the increasing resistance of pathogenic bacteria to current antibiotics, in-depth research to discover new antibacterial substances is of the utmost importance.

Endophytic fungi colonize intra- and inter-cellular plant tissues during all or part of their life cycle without causing apparent damages (Fouda et al., 2015). These microorganisms establish a symbiotic relationship with the host plant, in which the fungus obtains nutrients and shelter, while the plant receives protection against pathogens and insect-pests (Giménez et al., 2007; Alvin et al., 2014). Endophytes constitute a novel source of bioactive substances that may be employed in different biotechnological industries (Orlandelli et al., 2015), including aliphatic compounds, alkaloids, flavonoids, peptides, phenols, quinones, steroids and terpenoids with antimicrobial properties, reviewed by $\mathrm{Yu}$ et al. (2010). So that the biotechnological properties of these fungi could be expanded, current study establishes the chemical characteristics of the secondary metabolites produced by two endophytes isolated and molecularly identified from passion fruit plants and reports their antibacterial activity against Enterococcus faecalis, Salmonella typhi and Streptococcus pyogenes.

\section{MATERIALS AND METHODS}

\section{Endophytic fungi}

The endophytes tagged as PE1-13 and PA8-2, belonging to the fungal culture collection of the Laboratório de Biotecnologia Microbiana, Universidade Estadual de Maringá, Maringá PR Brazil, were isolated from Passiflora edulis f. flavicarpa and Passiflora alata, respectively. For fungal isolation, healthy Passiflora leaves were collected from the University's Experimental Didactic Garden, washed in running tap water and in an aqueous solution $0.01 \%$ Tween 80 to remove epiphyllous debris. The leaves were then rinsed with $70 \%$ ethanol for $1 \mathrm{~min}$, surface-disinfected with sodium hypochlorite solution (4\% available $\mathrm{Cl}^{-}$) for $3 \mathrm{~min}$, and rinsed in $70 \%$ ethanol (30 s) and twice in sterile distilled water. Leaves were cut into 5$\mathrm{mm}^{2}$ fragments and equally placed on Potato Dextrose Agar (PDA) dishes to which tetracycline was added. All dishes were incubated at $28^{\circ} \mathrm{C}$ in biochemical oxygen demand (BOD) for seven days and periodically checked (Silva et al., 2013). Fungi were maintained on PDA medium (HiMedia, Mumbai, MH, India) at $4^{\circ} \mathrm{C}$.

\section{Molecular identification}

Genomic DNA was extracted according to Felber et al. (2015). DNA concentration and integrity were analyzed by electrophoresis in 1\% agar gel with Lambda DNA digested by HindIII (Gibco-Invitrogen, Carlsbad, CA, USA) as molecular weight standard. PCR amplification of ITS1-5.8S-ITS2 of rDNA region was performed according to Magnani et al. (2005) with primers ITS1 (5'-TCCGTAGGTGAACCTGCGG-3') and ITS4 (5'TCCCCGCTTATTGATATGC-3') (White et al., 1990) with an initial denaturation at $92^{\circ} \mathrm{C}$ for $4 \mathrm{~min}$, followed by 35 denaturation cycles at $92{ }^{\circ} \mathrm{C}$ for $40 \mathrm{~s}$, annealing at $52^{\circ} \mathrm{C}$ for $1 \mathrm{~min}$ and $30 \mathrm{~s}$, extension at $72^{\circ} \mathrm{C}$ for $2 \mathrm{~min}$ and a final extension at $72^{\circ} \mathrm{C}$ for $5 \mathrm{~min}$. PCR products were purified with GFX PCR DNA kit and Gel Band Purification (Amersham Biosciences, Piscataway, NJ, USA), following manufacturer's instructions.

Sequencing was performed in a MegaBACE TM 1000 sequencer (Amersham Biosciences), with injection and electrophoresis conditions of $2 \mathrm{kV} / 60 \mathrm{~s}$ and $6 \mathrm{kV} / 230 \mathrm{~min}$, respectively. Nucleotide sequences were analyzed and edited, and compared to those deposited in GenBank (http://www.ncbi.nlm.nih.gov). The BLASTN program was used for research into genera or species. Determination was based on the best result obtained for identity. In the case of phylogenetic analysis, a dendrogram was constructed with the sequences obtained coupled to those available in the GenBank. Sequences were aligned by Clustal X (Thompson et al., 1997) and the dendrogram was constructed by MEGA program version 6 (Tamura et al., 2013) with grouping by the neighbor-joining method (Saitou and Nei, 1987), using p-distance for nucleotides with the option of pair-wise gap deletion and bootstrap with 10,000 replications.

\section{Extraction of secondary metabolites}

A slightly modified version of the protocol described by Rukachaisirikul et al. (2008) was used to obtain secondary metabolites. Endophytes were grown on PDA at $28{ }^{\circ} \mathrm{C}$ for seven days. Further, three 5- $\mathrm{mm}^{2}$ mycelium fragments of each endophyte were inoculated into 500-mL Erlenmeyer flasks containing 250 $\mathrm{mL}$ of Potato Dextrose Broth (PDB) (HiMedia, Mumbai, MH, India) and incubated at $28^{\circ} \mathrm{C}$ for 25 days under stationary condition. Broth cultures were then filtered with sterile gauze to separate the fungal mycelia, which were discarded. The cell-free media were centrifuged at $1300 \times g$ for 20 min to separate cellular debris.

The supernatants were transferred to a separating funnel in which ethyl acetate (EtOAc) P.A. (Fmaia, Cotia, SP, Brazil) was added at a ratio of 1:5. After strong agitation, the separation of phases occurred by polarity difference and the EtOAc phase was collected. After extracting the fermented medium three more times with EtOAc, the solvent was removed by $98 \%$ concentration in a MA-120 rotary evaporator (Marconi, Piracicaba SP Brazil) at $40^{\circ} \mathrm{C}$. The metabolites were tagged $\mathrm{SM}_{\mathrm{PEl} 1-13}$ and $\mathrm{SM}_{\mathrm{PA} 8-2}$.

\section{Chemical characterization of secondary metabolites}

Thin layer chromatography (TLC) was carried out on 20 $\times 20 \mathrm{~cm}$ glass plates with silica gel $60 \mathrm{G}$ and 60 GF254 (Merck, Darmstadt, HE, Germany), suspended in distilled water at a ratio of 1:2, and distributed at an approximate thickness of $0.25 \mathrm{~mm}$. Plates were dried at $120^{\circ} \mathrm{C}$ for $30 \mathrm{~min}$ before use. They were developed in organic solvents hexane, dichloromethane, methanol and ethyl acetate, at a polarity-increasing order $(0,3.1,5.1$ and 6.2, respectively), used in pure form or as binary mixtures. Chromatograms were developed by the ascending technique in which each plate was immersed in the developing solvent to a depth of $\sim 0.5 \mathrm{~cm}$. Plates were then washed and dried at room 
temperature and spots on TLC plates were visualized by spraying with Liebermann-Burchard reagent (to detect steroids/ triterpenoids) and with Dragendorff reagent (to detect alkaloids).

\section{Antibacterial activity assay}

Enterococcus faecalis ATCC 29212, Salmonella typhi ATCC 19430 and Streptococcus pyogenes ATCC 19615 were selected for the antibacterial activity assay. They were grown in Luria Bertani Broth (LBB) (Sambrook and Russel, 2001) for $24 \mathrm{~h}$ at $37^{\circ} \mathrm{C}$, and the diluted bacterial suspension $\left(1.5 \times 10^{8} \mathrm{cfu} \mathrm{mL}^{-1}\right)$ was ready for detection. A modified version of MTT [3-(4,5dimethylthiazol-2-yl)-2,5-dephenyl tetrazolium bromide] assay (Zhao et al, 2010) was used to detect the antibacterial activity of $\mathrm{SM}_{\mathrm{PE1-13}}$ and $\mathrm{SM}_{\mathrm{PA} 8-2}$. Briefly, the metabolites were dissolved in $2.5 \%$ DMSO solution (in LBB) at an initial concentration of 1000 $\mu \mathrm{g} . \mathrm{mL}-1$, and then diluted with LBB to obtain the following concentrations: 100, 200, 300, 400, 500, 600, 700, 800, 900, 1000 $\mu \mathrm{g} \mathrm{mL}^{-1}$. The tetracycline (Sigma-Aldrich, St. Louis, MO, USA) solution, used as positive control, was prepared under the same conditions.

Aliquots of each bacterial solution $(5 \mu \mathrm{L})$ and $\mathrm{LB}(100$ $\mu \mathrm{L}$ ) were applied in each well of 96-well plates (except for blank wells). The bacteria were treated (three replicates) with $100 \mu \mathrm{L}$ of secondary metabolite solution (100-1000 $\mu \mathrm{g} \mathrm{mL}$ ), Tetracycline solution (100-1000 $\mu \mathrm{g} \mathrm{mL-1)}$ or $2.5 \%$ DMSO solution (negative control).

After incubation for $24 \mathrm{~h}$ at $37^{\circ} \mathrm{C}$, the treatments were discarded and $10 \mu \mathrm{L}$ of MTT solution $\left(5 \mathrm{mg} \mathrm{mL}^{-1}\right.$ in LBB) was added to each well. Plates were centrifuged at $1300 \times \mathrm{g}$ for $20 \mathrm{~min}$, the supernatants were discarded and $150 \mu \mathrm{L}$ of DMSO were added. Plates were kept at room temperature for $30 \mathrm{~min}$ and absorbance was measured at $550 \mathrm{~nm}$ in a FlexStation microplate reader (Molecular Devices, Sunnyvale, CA, USA). Absorbance means of negative control was taken as $100 \%$ of bacterial growth. The inhibition ratio (\%) was calculated as follows (1):

$$
\text { Inhibition ratio }(\%)=\frac{A_{C}-A_{T}}{A_{C}} \times 100
$$

where: $A_{T}$ and $A_{C}$ were the absorbance means measured for treated groups and negative control group, respectively. Data were analyzed by analysis of variance (ANOVA) and averages were compared by Tukey test $(\mathrm{p}<0.05)$ with statistical program SISVAR 5.3 .

\section{RESULTS AND DISCUSSION}

\section{Molecular identification of endophytes}

The sensitivity and specificity of molecular biology techniques employed for the genetic differentiation of species forwarded important advances in the identification of fungal species. The amplification of the internal transcribed spacer region (ITS) of ribosomal DNA (rDNA) by the polymerase chain reaction (PCR) is frequently used. Further, rDNA-ITS sequences obtained may be compared to those available at GenBank database (Magnani et al., 2005). Herein, molecular techniques were employed to identify two fungal endophytes isolated from passion fruit plants. Sequencing of ITS1-5.8S-ITS2 regions identified the two endophytes isolated from passion fruit plants (Table 1 and Figure 1).

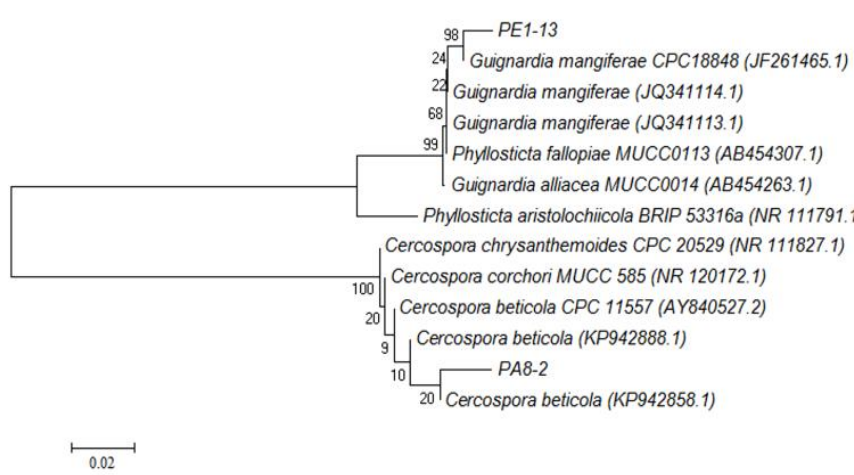

Fig. 1: The evolutionary history was inferred by the Neighbor-Joining method. The percentage of replicate trees in which the associated taxa clustered together in the bootstrap test $(10,000$ replicates) is shown next to the branches. The evolutionary distances were computed by p-distance method and are in the units of the number of base differences per site. Evolutionary analyses were conducted in MEGA6.

Isolate PE1-13 (98\% identity with Phyllosticta fallopiae MUCC0113 at BLAST) was grouped with Phyllosticta (= Guignardia) genus with $99 \%$ BP, confirming classification at genus level. Sequence data were submitted to GenBank under accession number KU641754. After the deletion of art. 59 from the International Code of Nomenclature for Algae, Fungi, and Plants, valid since January 2013, the asexual and sexual names of fungi received equal status and binomial nomenclature was replaced by a single name based on priority. Since the genus Phyllosticta was introduced by Persoon in 1818 (a much older name than Guignardia introduced by Viala and Ravaz in 1892), Phyllosticta has been currently used as the legitimate genus name. Species belonging to this genus have been reported as plant pathogens (Stringari et al., 2009; Escanferla et al., 2009) and several strains have already been isolated as endophytes as, for instance, from the mangrove plants Laguncularia racemosa and Rhizophora mangle (Costa et al., 2012), and from the medicinal plants Piper hispidum (Orlandelli et al., 2012) and Luehea divaricata (Bernardi-Wenzel et al., 2010).

Isolate PA8-2 (99\% identity with Cercospora beticola CPC 11557 at BLAST) was grouped with Cercospora genus with $100 \%$ BP and grouped with $C$. beticola with $20 \%$ BP, confirming the species' classification. Sequence data were submitted to GenBank under accession number KU641755. The fungus genus has been commonly associated with leaf spots on a wide range of host plants such as maize (Zea mays), faba bean (Vicia faba)and sugar beet (Beta vulgaris) (Meisel et al., 2009; Kimber and Paull, 2011; de Coninck et al., 2012). Recently, the genus was reported as an endophyte from the macrophytes Eichhornia azurea and Eichhornia crassipes (Almeida et al., 2015). 
Table 1: Molecular identification of endophytic strains based on the alignment of ITS region sequences with those deposited at GenBank and phylogenetic analyses.

\begin{tabular}{|c|c|c|c|c|c|c|}
\hline \multicolumn{4}{|c|}{ Endophytes from Passiflora plants } & \multicolumn{3}{|c|}{ Closely related GenBank sequences } \\
\hline Code & Host & Identification & Genbank code & Fungal species & GenBank code & Similarity \\
\hline PE1-13 & P. edulis f. flavicarpa & Phyllosticta sp. & KU641754 & Phyllosticta fallopiae MUCC0113 & $\mathrm{AB} 454307.1$ & $98 \%$ \\
\hline PA8-2 & P. alata & Cercospora beticola & KU641755 & Cercospora beticola CPC 11557 & AY840527.2 & $99 \%$ \\
\hline
\end{tabular}

Table 2: Antibacterial activity of secondary metabolites obtained from endophytic fungi against Enterococcus faecalis ATCC 29212, Salmonella typhi ATCC 19430 and Streptococcus pyogenes ATCC 19615.

\begin{tabular}{|c|c|c|c|c|c|c|c|c|c|}
\hline \multirow{2}{*}{$\begin{array}{l}\text { Treatment }(\mu \mathrm{g} \\
\left.\mathrm{mL}^{-1}\right)\end{array}$} & \multicolumn{3}{|c|}{ Enterococcus faecalis* } & \multicolumn{3}{|c|}{ Salmonella typhi* } & \multicolumn{3}{|c|}{ Streptococcus pyogenes* } \\
\hline & $\overline{\mathbf{S M}}_{\mathbf{P A 8 - 2}}$ & $\mathbf{S M}_{\mathrm{PE1}-13}$ & PC & $\mathbf{S M}_{\mathbf{P A 8 - 2}}$ & SM $_{\text {PE1-13 }}$ & PC & $\mathbf{S M}_{\mathbf{P A 8 - 2}}$ & SM $_{\text {PE1-13 }}$ & PC \\
\hline 100 & $80.7 \pm 3.8^{c}$ & $93.9 \pm 1.4^{\mathrm{a}}$ & $79.8 \pm 5.9^{\mathrm{c}}$ & - & $80.3 \pm 1.0^{c}$ & $102.2 \pm 4.7^{\mathrm{a}}$ & $94.2 \pm 0.8^{\mathrm{a}}$ & $97.1 \pm 0.5^{\mathrm{a}}$ & $91.9 \pm 3.1^{a}$ \\
\hline 200 & $83.0 \pm 2.3^{\mathrm{c}}$ & $96.2 \pm 3.7^{\mathrm{a}}$ & $74.2 \pm 4.9^{\mathrm{c}}$ & - & $78.9 \pm 2.8^{\mathrm{c}}$ & $103.6 \pm 5.2^{\mathrm{a}}$ & $92.9 \pm 2.4^{\mathrm{a}}$ & $96.9 \pm 1.1^{\mathrm{a}}$ & $90.6 \pm 2.7^{\mathrm{a}}$ \\
\hline 300 & $81.0 \pm 0.2^{c}$ & $93.8 \pm 8.9^{\mathrm{a}}$ & $71.6 \pm 0.9^{c}$ & - & $84.3 \pm 8.6^{c}$ & $104.1 \pm 4.2^{\mathrm{a}}$ & $92.7 \pm 1.9^{\mathrm{a}}$ & $94.2 \pm 0.9^{\mathrm{a}}$ & $88.3 \pm 2.0^{\mathrm{b}}$ \\
\hline 400 & $80.1 \pm 3.0^{c}$ & $90.4 \pm 1.0^{\mathrm{a}}$ & $70.8 \pm 3.5^{\mathrm{c}}$ & - & $89.5 \pm 9.1^{\mathrm{b}}$ & $103.3 \pm 2.1^{\mathrm{a}}$ & $93.4 \pm 0.4^{\mathrm{a}}$ & $93.9 \pm 3.1^{\mathrm{a}}$ & $87.2 \pm 3.2^{\mathrm{b}}$ \\
\hline 500 & $81.3 \pm 3.4^{\mathrm{c}}$ & $96.1 \pm 3.3^{\mathrm{a}}$ & $67.6 \pm 4.4^{\mathrm{c}}$ & $3.2 \pm 0.5^{\mathrm{g}}$ & $88.0 \pm 4.3^{\mathrm{b}}$ & $101.6 \pm 3.1^{\mathrm{a}}$ & $93.3 \pm 1.0^{\mathrm{a}}$ & $93.8 \pm 1.7^{\mathrm{a}}$ & $86.0 \pm 2.3^{\mathrm{b}}$ \\
\hline 600 & $78.4 \pm 1.6^{\mathrm{c}}$ & $94.8 \pm 3.3^{\mathrm{a}}$ & $64.8 \pm 4.2^{\mathrm{d}}$ & $18.4 \pm 2.4^{\mathrm{f}}$ & $90.2 \pm 0.3^{\mathrm{b}}$ & $99.8 \pm 4.9^{\mathrm{a}}$ & $92.1 \pm 1.3^{\mathrm{a}}$ & $92.4 \pm 1.3^{\mathrm{a}}$ & $84.5 \pm 3.5^{\mathrm{c}}$ \\
\hline 700 & $80.4 \pm 1.2^{\mathrm{c}}$ & $93.5 \pm 4.6^{\mathrm{a}}$ & $62.4 \pm 3.0^{\mathrm{d}}$ & $37.9 \pm 2.4^{\mathrm{e}}$ & $94.2 \pm 2.7^{b}$ & $90.4 \pm 2.2^{\mathrm{b}}$ & $91.7 \pm 0.1^{\mathrm{c}}$ & $93.8 \pm 1.7^{\mathrm{a}}$ & $81.7 \pm 1.1^{\mathrm{c}}$ \\
\hline 800 & $80.5 \pm 1.3^{\mathrm{c}}$ & $92.2 \pm 4.3^{\mathrm{a}}$ & $61.7 \pm 3.7^{\mathrm{d}}$ & $59.9 \pm 0.3^{\mathrm{d}}$ & $98.1 \pm 0.5^{\mathrm{a}}$ & $90.7 \pm 8.8^{\mathrm{b}}$ & $91.9 \pm 1.8^{\mathrm{a}}$ & $93.4 \pm 3.1^{\mathrm{a}}$ & $83.4 \pm 4.0^{\mathrm{c}}$ \\
\hline 900 & $79.2 \pm 1.0^{\mathrm{c}}$ & $95.7 \pm 2.1^{\mathrm{a}}$ & $62.6 \pm 3.0^{\mathrm{d}}$ & $62.9 \pm 4.1^{\mathrm{d}}$ & $97.6 \pm 0.5^{\mathrm{a}}$ & $87.8 \pm 3.1^{\mathrm{b}}$ & $91.1 \pm 1.3^{\mathrm{a}}$ & $93.6 \pm 4.6^{\mathrm{a}}$ & $82.3 \pm 4.7^{\mathrm{c}}$ \\
\hline 1000 & $79.7 \pm 4.7^{\mathrm{c}}$ & $93.8 \pm 5.7^{\mathrm{a}}$ & $61.1 \pm 1.9^{\mathrm{d}}$ & $79.6 \pm 2.1^{\mathrm{c}}$ & $93.9 \pm 0.0^{\mathrm{b}}$ & $79.3 \pm 2.3^{\mathrm{c}}$ & $91.1 \pm 0.2^{\mathrm{a}}$ & $93.0 \pm 4.3^{\mathrm{a}}$ & $81.5 \pm 5.4^{\mathrm{c}}$ \\
\hline
\end{tabular}

Note: *For each bacterium, means followed by different letters are significantly different according to Scott-Knott test $(\mathrm{p}<0.05)$.

Abbreviations: SMPA8-2 = secondary metabolite from Cercospora beticola KU641755; SMPE1-13 = secondary metabolite from Phyllosticta sp. KU641754; PC $=$ positive control, that is, Tetracycline (Sigma-Aldrich).

\section{TLC chromatography of secondary metabolites}

Dragendorff test for alkaloids was negative for metabolic extracts from Phyllosticta sp. KU641754 (SM $\left.\mathrm{SMI}_{\mathrm{PE1} 13}\right)$ and Cercospora beticolaKU641755 ( $\left.\mathrm{SM}_{\mathrm{PA8}-2}\right)$, whereas both extracts were positive by Liebermann-Burchard test for steroids and triterpenoids. Manufactured steroid compounds may be used for therapeutic purposes, as anti-inflammatory, immunosuppressive, progestational, diuretic, anabolic and contraceptive drugs (Bracco et al., 2013). Terpenoids and triterpenoids are described as potent antimycobacterial agents (Cantrell et al., 2001; Jadulco et al., 2011).

When the chromatoplates were analyzed with pure solvents, the metabolic extracts showed a better resolution and distribution of substances with the dichloromethane solvent, which has intermediate polarity. Therefore, analyses were performed with different proportions of a binary mixture of dichloromethane and ethyl acetate. The proportion of 50\% dichloromethane and 50\% ethyl acetate provided the best separation of the compounds contained in $\mathrm{SM}_{\mathrm{PE1}-13}$ when compared to the use of $100 \%$ dichloromethane as a mobile phase. Since acetate increased the phase's polarity, the compounds left the point of origin and they were carried by the column, being visually more separated. On the contrary, the best separation of $\mathrm{SM}_{\mathrm{PA} 8-2}$ occurred when $100 \%$ dichloromethane was used.

Herein, the production of steroids and triterpenoids by Phyllosticta and Cercospora endophytes was reported. The genus Phyllosticta is often reported due to its capacity of producing phytotoxins, including phyllostoxin and phyllostin for the production of herbicides (Evidente et al, 2008). Moreover, Kumaran et al. (2009) reported the isolation and identification of an anticancer drug taxol from P. tabernaemontanae. Cercospora beticola is the economically most important foliar pathogen of sugar beet (Beta vulgaris). The latter and other Cercospora species are mainly described due to the production of cercosporin, a photo-activated toxin that generates reactive oxygen species when exposed to light (Staerkel et al., 2013).

\section{Antibacterial activity of secondary metabolites}

As seen in Table 2, all concentrations of $\mathrm{SM}_{\mathrm{PE1}-13}$ (from Phyllosticta sp. KU641754) were effective against E. faecalis ATCC 29212, with highest inhibition ratio at $96.2 \pm 3.7 \%$. This result was statistically more effective than that obtained for $\mathrm{SM}_{\mathrm{PA} 8-}$ ${ }_{2}$ (from C. beticola KU641755) and positive control. Similarly, the inhibition ratio for $\mathrm{SM}_{\mathrm{PEI}-13}$ (up to $98.1 \pm 0.5 \%$ ) was higher than that described for $\mathrm{SM}_{\mathrm{PA8}-2}$ (up to $79.6 \pm 2.1 \%$ ) when the bacterium $S$. typhi ATCC 19430 was tested. In the case of the antibacterial activity against $S$. pyogenes ATCC 19615, the two metabolites showed positive results with an inhibition ratio of $94.2 \pm 0.8 \%$ $\left(\mathrm{SM}_{\mathrm{PA} 8-2}\right)$ and $97.1 \pm 0.5 \%\left(\mathrm{SM}_{\mathrm{PE1} 13}\right)$.

Current study is the first report on antibacterial activity of $C$. beticola metabolites. In the case of Phyllosticta species, the metabolic extracts were already investigated against Escherichia coli, Bacillus cereus, Bacillus subtilis, Micrococcus luteus and Pseudomonas aeruginosa (Wikee et al., 2013; Chukeatirote et al., 2015). There are no reports in the literature on the effects of Phyllosticta metabolites against E. faecalis, S. typhi and S. pyogenes. Therefore, further studies should be undertaken to provide in-depth knowledge on antibacterial properties of these fungal metabolites.

\section{CONCLUSIONS}

Research on microbial sources of bioactive compounds with commercial interest is of great importance to replace those of animal and plant origin, which are subject to predation, extractive activity and consequent extinction. Moreover, the obtainment of 
natural compounds involves lower costs and environmental impacts when compared to those obtained by synthetic routes. In fact, current investigation revealed that $C$. beticola KU641755 and Phyllosticta sp. KU641754 are potential sources of steroid and triterpenoid metabolites with antibacterial action against $E$. faecalis, S. typhi and S. pyogenes.

\section{ACKNOWLEDGEMENTS}

The authors are grateful to CNPq (311534/2014-7 and 447265/2014-8) and Fundação Araucária (276/2014) for financial support. M.S. Santos was recipient of an undergraduate scholarship from CNPq/PIBIC.

Conflict of Interests: There are no conflicts of interest.

\section{REFERENCES}

Almeida TT, Orlandelli RC, Azevedo JL, Pamphile J A. Molecular characterization of the endophytic fungal community associated with Eichhornia azurea (Kunth) and Eichhornia crassipes (Mart.) (Pontederiaceae) native to the Upper Paraná River floodplain, Brazil. Genetics and Molecular Research, 2015; 2:4920-4931.

Alvin A, Miller KI, Neilan B A. Exploring the potential of endophytes from medicinal plants as sources of antimycobacterial compounds. Microbiological Research, 2014; 7:483-495.

Arias CA, Murray BE. Emergence and management of drugresistant enterococcal infections. Expert Review of Anti-infective Therapy, 2008; 6:637-655.

Arias CA, Murray BE. The rise of the Enterococcus: beyond vancomycin resistance. Nature Reviews Microbiology, 2012; 10:266-278.

Bernardi-Wenzel J, Garcia A, Rubin Filho CJ, Prioli, AJ, Pamphile, JA. Evaluation of foliar fungal endophyte diversity and colonization of medicinal plant Lueheadivaricata (Martius et Zuccarini). Biological Research, 2010; 4:375-384.

Bracco P, Janssen DB, Schallmey A. (2013). Selective steroid oxyfunctionalisation by CYP154C5, a bacterial cytochrome P450. Microbial Cell Factories, 2013; 95, doi: 10.1186/14752859-12-95.

Breidenstein EBM, Courvalin P, Meziane-Cherif D. Antimicrobial Activity of Plectasin NZ2114 in Combination with Cell Wall Targeting Antibiotics Against VanA-Type Enterococcus faecalis. Microbial Drug Resistance, 2015;4:373- 379.

Cantrell CL, Franzblau SG, Fischer NH. Antimycobacterial plant terpenoids. Planta Medica, 2001; 8:685-694.

Chukeatirote E, Wikee S, Hyde KD. Diversity and antibacterial activity of Phyllosticta species. Micologia Aplicada International, 2015; $1: 1-9$.

Costa IPMW, Maia LC, Cavalcanti MA. Diversity of leaf endophytic fungi in mangrove plants of northeast Brazil. Brazilian Journal of Microbiology, 2012; 3:1165-1173.

Crump J A, Mintz ED. Global trends in typhoid and paratyphoid fever. Clinical Infectious Diseases, 2010; 50:241-246.

De Coninck BMA, Amand O, Delauré SL, Lucas S, Weyens N, Cammue BPA. The use of digital image analysis and real-time PCR finetunes bioassays for quantification of Cercospora leaf spot disease in sugar beet breeding. Plant Pathology, 2012; 1:76-84.

Escanferla ME, Moraes SRG, Salaroli RB, Massola Jr NS. Prepenetration stages of Guignardia psidii in guava: effects of temperature, wetness duration and fruit age. Journal of Phytopathology, 2009; 10:618-624.

Evidente A, Cimmino A, Andolfi A, Vurro M, Zonno MC, Motta A. Phyllostoxin and Phyllostin, bioactive metabolites produced by Phyllosticta cirsii, a potential mycoherbicide for Cirsium arvense biocontrol. Joural Agricultural and Food Chemistry, 2008; 3:884-888.
Felber AC, Orlandelli RC, Rhoden SA, Garcia A, Costa AT, Azevedo JL, Pamphile JA. Bioprospecting foliar endophytic fungi of Vitis labrusca Linnaeus, Bordô and Concord cv. Annals of Microbiology, 2015, doi 10.1007/s13213-015-1162-6.

Fouda AH, Hassan SED, Eid AM, Ewais EED Biotechnological applications of fungal endophytes associated with medicinal plant Asclepias sinaica (Bioss.). Annals of Agricultural Sciences, 2015; 1:95-104.

Giménez C, Cabrera R, Reina M, González-Coloma A. Fungal endophytes and their role in plant protection. Current Organic Chemistry, 2007; 8:707720 .

Gregersen RH, Petersen A, Christensen H, Bisgaard M. Multilocus sequence typing of Enterococcus faecalis isolates demonstrating different lesion types in broiler breeders. Avian Pathology, 2010; 39:435-440.

Jadulco RC, Koch M, Van Wagoner RM, Pond C, Gideon OG, Matainaho T, Piskaut P, Barrows LR. New antimycobacterial triterpenoids from Rhus taitensis. Planta Medica, 2011; 14:1651-1654.

Kimber RBE, Paull JG. Identification and genetics of resistance to cercospora leaf spot (Cercospora zonata) in faba bean (Vicia faba). Euphytica, 2011; 3:419-429.

Kumaran RS, Muthumary J, Hur BK. Isolation and identification of an anticancer drug, taxol from Phyllosticta tabernaemontanae, a leaf spot fungus of an angiosperm, Wrightia tinctoria. Journal of Microbiology, 2009; 1:40-49.

Magnani M, Fernandes T, Prete CEC, Homechim M, Ono EYS, Vilas-Boas LA, Fungaro MHP. Molecular identification of Aspergillus spp. isolated from coffee beans. Scientia Agricola, 2005; 1:45-49.

Meisel B, Korsman J, Kloppers FJ, Berger DK. Cercospora zeina is the causal agent of grey leaf spot disease of maize in southern Africa. European Journal of Plant Pathology, 2009; 4:577-583.

Nguanhom J, Cheewangkoon R, Groenewald JZ, Braun U, ToAnun C, Crous PW. Taxonomy and phylogeny of Cercospora spp. from Northern Thailand. Phytotaxa, 2015; 1:27-48.

Orlandelli RC, Alberto RN, Rubin Filho CJ, Pamphile JA. Diversity of endophytic fungal community associated with Piper hispidum Sw. (Piperaceae) leaves. Genetics and Molecular Research, 2012; 2:15751585 .

Orlandelli RC, Almeida TT, Alberto RN, Polonio JC, Azevedo JL, Pamphile JA. Antifungal and proteolytic activities of endophytic fungi isolated from Piper hispidum Sw. Brazilian Journal of Microbiology, 2015; 2:359-366.

Rubio-López V, Valdezate S, Álvarez D, Villalón P, Medina MJ, Salcedo C, Sáez-Nieto JA. Molecular epidemiology, antimicrobial susceptibilities and resistance mechanisms of Streptococcus pyogenes isolates resistant to erythromycin and tetracycline in Spain (1994-2006). BMC Microbiology, 2012; 215, doi: 10.1186/1471-2180-12-215.

Rukachaisirikul V, Sommart U, Phongpaichit S, Sakayaroj J,Kirtikara K. Metabolites from the endophytic fungus Phomopsis sp. PSU-D15. Phytochemistry, 2008; 3:783-787.

Saitou N, Nei M. The neighbor-joining method: a new method for reconstructing phylogenetic trees. Molecular Biology Evolution, 1987; 4:406-425

Sambrook J, Russel DW. 2001. Molecular cloning: a laboratory manual. Cold Spring Harbor Laboratory Press.

Silva MCS, Santos, MS, Rhoden AS, Garcia A, Almeida TT, Felber AC, Azevedo JL, Pamphile JA. Isolamento e avaliação da atividade antagonística de fungos endofíticos de Passiflora spp. (Passifloraceae) contra fungos fitopatogênicos. In: $27^{\circ}$ Congresso Brasileiro de Microbiologia, $29^{\text {th }}$ September $-3^{\text {th }}$ October 2013, Natal, Rio Grande do Norte, Brazil.

Siljander O, Lyytikäinen S, Vähäkuopus M, Snellman J, Jalava J. Epidemiology, outcome and emm types of invasive group A streptococcal infections in Finland. European Journal of Clinical Microbiology and Infectious Diseases, 2010; 29:1229-1235.

Silva-Costa C, Friães A, Ramirez M, Melo-Cristino J. Differences between acrolide-resistant and -susceptible Streptococcus pyogenes: importance of clonal properties in addition to antibiotic 
consumption. Antimicrobial Agents and Chemotherapy, 2012; 56:56615666.

Staerkel C, Boenisch MJ, Kröger C, Bormann J, Schäfer W, Stahl D. CbCTB2, an O-methyltransferase is essential for biosynthesis of the phytotoxin cercosporin and infection of sugar beet by Cercospora beticola. BMC Plant Biology, 2013; 50, doi: 10.1186/1471-2229-13-50.

Stringari D, Glienke C, Christo D, Maccheroni Júnior W, Azevedo JL. High molecular diversity of the fungus Guignardia citricarpa and Guignardia mangiferae and new primers for the diagnosis of the citrus black spot. Brazilian Archives of Biology and Tecnhology, 2009; 5:10631073 .

Tamura K, Stecher G, Peterson D, Filipski A, Kumar S. MEGA6: Molecular Evolutionary Genetics Analysis Version 6.0. Molecular Biology and Evolution, 2013; 12:2725-2729.

Thompson JD, Gibson TJ, Plewniak F, Jeanmougin F, Higgins DG. The ClustalX windows interface: flexible strategies for multiple sequence alignment aided by quality analysis tools. Nucleic Acids Research, 1997; 24:4876-4882.

Wasserzug O, Valinsky L, Klement E, Bar-Zeev Y, Davidovitch $\mathrm{N}$, Orr N, ... Zarka S. A cluster of ecthyma outbreaks caused by a single clone of invasive and highly infective Streptococcus pyogenes. Clinical Infectious Diseases, 2009; 48:1213-1219.

Wikee S, Jaidee P, Wongkam S, Mckenzie EHC, Hyde KD, Chukeatirote E. Antimicrobial activity of crude extracts of Phyllosticta spp. Mycology: An International Journal on Fungal Biology,2013; 2:112117.

White TJ, Bruns T, Lee S, Taylor, J. Amplification and direct sequencing of fungal ribosomal RNA genes for phylogenetics. In: Innis, M. A., Gelfland, D. H., Sninsky, J. J., \& White, T. J. (eds) PCR Protocols. A Guide to Methods and Applications. Academic, 1990; 315-322.
Wong MHY, Yan M, Chan EWC, Biao K, Chen S. Emergence of clinical Salmonella enterica serovar Typhimurium isolates with concurrent resistance to ciprofloxacin, ceftriaxone, and azithromycin. Antimicrobial Agents and Chemotherapy, 2014; 7:3752-3756.

Yu H, Zhang L, Li L, Zheng C, Guo L, Li W, ... Qin L. Recent developments and future prospects of antimicrobial metabolites produced by endophytes. Microbiological Research, 2010; 6:437-449.

Zhao J, Mou Y, Shan T, Li Y, Zhou L, Wang M, Wan J. Antimicrobial metabolites from the endophytic fungus Pichia guilliermondii isolated from Paris polyphylla var. yunnanensis. Molecules, 2010; 11:7961-7970.

\section{How to cite this article:}

Santos MS, Orlandelli RC, Polonio JC, Ribeiro MAS, Sarragiotto MH, Azevedo JL, Pamphile JA. Endophytes isolated from passion fruit plants: molecular identification, chemical characterization and antibacterial activity of secondary metabolites. J App Pharm Sci, 2017; 7 (04): 038-043. 